\title{
Basic Investigation of COVID-19's Self Isolation Room in Various Residential Typology
}

\author{
Anggana Fitri Satwikasari ${ }^{1}$, Erni Setyowati ${ }^{2}$, Norhayati Mahyuddin ${ }^{3}$, Jundi Jundullah ${ }^{1}$, Evi \\ Puspitasari $^{1}$, Yudi Kurnia ${ }^{1}$ \\ ${ }^{1}$ Department of Architecture, Faculty of Engineering, Universitas Muhammadiyah Jakarta \\ ${ }^{2}$ Department of Architecture, Faculty of Engineering, Universitas Diponegoro \\ ${ }^{3}$ Department of Building Surveying, Faculty of Built Environment, University of Malaya \\ anggana.fitri@umj.ac.id
}

\begin{abstract}
The self-isolation room is one of the main additional re-adjusted rooms for the family who have the COVID19 infected member, especially those who get medical recommendations for staying at their homes instead of being treated in the medical facilities. Isolation is different from the term quarantine. People who is decided to be isolated is the one who tested positive COVID-19 and strictly have to be separated from the others. Meanwhile, quarantine is a 14-days limitation access for healthy people who have close contact with the infected person. This research aimed to gather and analyze the existing data of the isolation room's technical criteria on the COVID-19 Survivors' houses. The collecting data process used a questionnaire method that referred to the protocol's ten parameters related to architecture in the Indonesian Ministry of Health's Community-Based Shelter Facilities for Quarantine and Isolation Protocol During the Covid-19 Pandemic [1]. The collected data had been analyzed and presented in a bar chart as the visualization of the distributive analysis for each parameter. The sample houses were classified into four categories based on their home are, which would be category $1(9 \mathrm{~m} 2)$, category $2(9,1-50 \mathrm{~m} 2$, category $3(50,1-100 \mathrm{~m} 2)$, and category $4(>100 \mathrm{~m} 2)$.
\end{abstract}

(C) 2021 IJBESR. All rights reserved.

Keywords: Isolation Room, Architecture Investigation, Residential Typology, COVID-19,

Architecture Modelling

\section{Introduction}

In the previous research on 2015, we have found out that there were some significant effects of improving room's indoor comfort aspect-such as daylighting, natural ventilation, humidity, temperature, and indoor air quality (IAQ)-to increase the quality of occupant's health in Tuberculosis (TB) survivor's houses cases [1][2]. The result from that research later led to some following research related to similar topics, the influence of indoor comfort quality on occupant health [3]. Those researches were conducted by the problems that arose due to the unpredictable disease transmission in the house environment.
Furthermore, the concern continued in the recent phenomenon of COVID-19. COVID-19 outbreaks forced people in the world to implement the 'new-normal-lifestyle', including in terms of arranging their houses. Re-adjusting the function of the rooms inside their houses becomes very important, especially when a family member is positively diagnosed with the disease caused by the SARS-CoV-2 virus. They must be separated from the others. However, for the COVID-19 case, we barely found research that focused on dealing with a 'new-normal life' after the pandemic, especially regarding indoor comfort aspects. This mindset actually had been initiated a long time ago as we could see the 
precedent from the 'Sanatorium' built in the early 20th century to isolated TB patients from others which we might be familiar with the term 'Isolation Room' lately [4].

The self-isolation room (Ruang Isolasi Mandiri)-in Indonesia, this term was used to name the room in the house that had to have functioned as the isolation room like in the hospital is one of the main additional readjusted rooms for the family who has the infected member, especially for those who got a medical recommendation for staying at their homes, instead of being treated in the medical facilities [5]. These people are usually indicated with low-medium symptoms, and they have to stay in their own self-isolation room for approximately 14 days. In the Handbook for Prevention and Control of Coronavirus Disease [6], the transmission of the COVID-19 virus could occur through direct contact with infected people and indirect contact with surfaces or objects used on infected people. If someone was suspected or the transmission might have happened in an event, for instance, everyone involved must do the PCR test [7][8]. Later, if someone gets a positive result, two conditions will be applied, whether they must be quarantined or isolated. Isolation is different from the term quarantine [9]. People who are decided to be isolated is the one who tests positive and strictly has to be separated from the others. Meanwhile, quarantine is a 14-days limitation access for healthy people who have close contact with the infected person.

The main concept of the isolation room is to separate people who belong to quarantine/isolation categories from the surrounding community, with the active involvement of the local community/RT-RW in supporting the quarantine/isolation process, starting from collecting data on residents, involving a volunteer task force, coordinating with the nearest health facility, and providing positive consequences for fix the existing stigma. Even though the government has already released the guidance, the implementation has not been evaluated yet. In the guidance, the government stated that at least ten technical criteria must be provided to create an ideal Isolation Room for a house. This research aimed to gather and analyze the existing data of those criteria related to indoor comfort. The existing data were later analyzed with the distributive method [10] to result from the initial measurement for the following research stage.

\section{Material and Methods}

The initial stage of data collection is the distribution of questionnaires conducted online. The questionnaire contains 71 questions consisting of 1 respondent's identity section and ten physical parameters section referring to the Community-Based Shelter Facilities for Quarantine and Isolation Protocol During the Covid-19 Pandemic of the Indonesian Ministry of Health in 2020 [7]. 8 Selected Respondents were required to fill in answers based on their own experience in the Self-Isolation Room (ISOMAN). In addition, respondents were also asked to upload supplementary files such as photos of their facilities in each parameter to assess their self-isolation room's feasibility. The ten parameters mentioned above are as follows:

1. House's Existing Physical Condition And Ventilation

2. Terrace/Open Space Access

3. Location

4. Availability of Clean Water

5. Handwashing Facilities with Soap (CTPS)

6. Bathrooms

7. Laundry Facility

8. Sanitation And Drainage System

9. Trash/sewage management

10. Food Logistics

Furthermore, the collected data will be analyzed and presented in a bar chart to visualize the distributive analysis for each parameter. The sample houses will be classified 
into four categories based on their home are, which would be category $1(9 \mathrm{~m} 2)$, category 2 $(9,1-50 \mathrm{~m} 2$, category $3(50,1-100 \mathrm{~m} 2)$, and category $4(>100 \mathrm{~m} 2)$. The classification is intended to visualize the initial daylighting and ventilation system problem that later can be simulated since it's been known that both factors are considered as practical solutions to prevent virus transmission and to accelerate the recovery process. The following analysis stage is 3-dimensional modeling in four residential categories with different areas using SketchUp software. This step is intended to create model rooms of each housing category that can be used for natural lighting and ventilation simulation.

\section{Results and Discussions}

\section{a) Demographics}

The eight respondents consist of 3 males, of whom two are the parents/husbands, one is still a young boy aged 18 years old, and five are housewives. According to picture 1, it can be seen that the highest percentage of the COVID19 survivors is 20-30 years old and 31-50 years old, $37 \%$ and $38 \%$, respectively. Then in the 'Sick Duration' category, $75 \%$ of respondents stayed in the isolation room for 8-14 days. This data shows that the COVID-19 virus mostly infected the productive age (20-50 years), and the majority suffered from illness for approximately 14 days. However, in picture 2, it can be seen that the ratio of infected family members reaches $63 \%$ for those in the $>50 \%$ category. This indicates that more family members were infected than healthy during the self-isolation period.

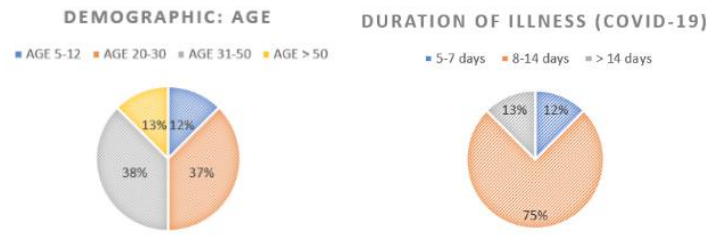

Source: Author's Analysis Figure 1: Demographic Percentage of COVID-19 Survivors' Age and Duration of Illness

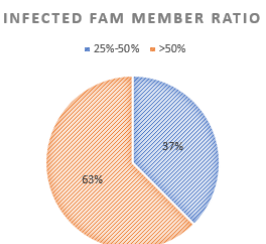

Source: Author's Analysis

Figure 2: Demographic Percentage of Infected Family Member Ration in COVID-19 Survivors' houses

\section{b) House's Existing Physical Condition And Ventilation}

The first parameter of the Isolation Room's Technical Criteria is House's Existing Physical Condition And Ventilation. $63 \%$ of 8 respondents live in landed houses, two live in boarding houses/dormitories, and one lives in apartments. All respondents represented each category from 4 classifications of house area, with details of 1 person living in a house area of $9 \mathrm{~m} 2$, two people living in 9.1-50 $\mathrm{m} 2$ house, two other people living in 50,1-100 $\mathrm{m} 2$ house, and the rest of respondent's houses sized $>100$ $\mathrm{m} 2$. All respondents stated that the isolation room used was one of the bedrooms in their houses, although only $50 \%$ had a separate room. In contrast, the rest used the same room with healthy family members because several were breastfeeding mothers, and a respondent was still under 12 years old. 


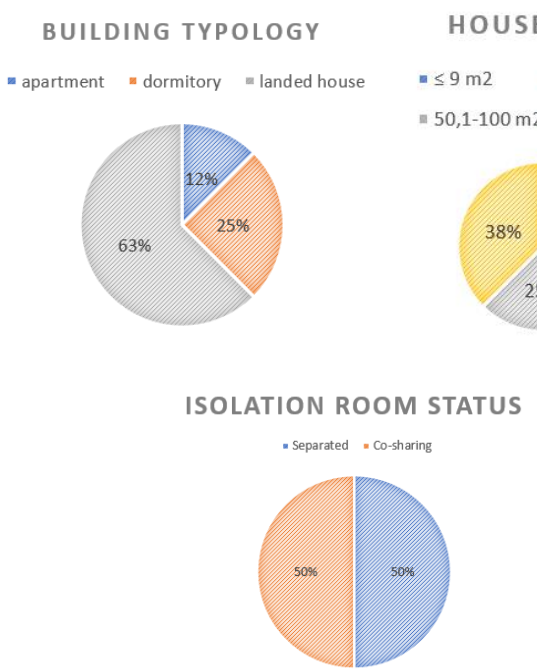

Source: Author's Analysis

Figure 3: The Percentage of COVID-19 Survivors' House Typology (left), the House Area (right), and Isolation Room Status (bottom)

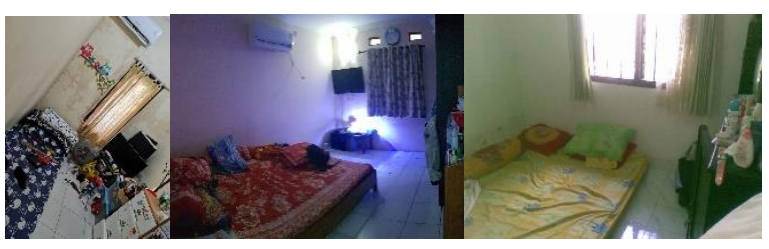

Source: Respondent's Documentation Figure 4: Some of the bedrooms as COVID-19's

Survivor's Isolation Room (existing)

Regarding the ventilation aspect in the selfisolation room, which affects the quality of natural air and daylighting, respondents were asked to fill in the ventilation, ventilation dimensions, and the isolation room dimension, which would be the calculation components of the window-to-floor ratio (WFR). WFR calculation is an indicator of the natural lighting and ventilation system feasibility. It is based on divisions of the ventilation dimension in a room to the room's dimension. From the results shown in Figure 5 below, it can be seen that $67 \%$ of the ventilation quality in the eight respondents' isolation rooms is still below the standard, which should be at least 10\% (RI M. P., 2002).

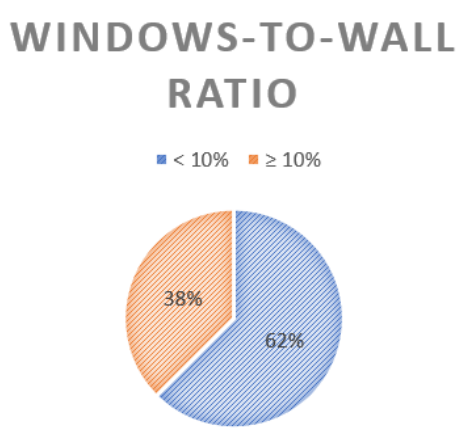

Source: Author's Analysis

Figure 5: The Percentage of COVID-19 Survivors' Isolation Room's Windows-to-wall ratio (WWR)

\section{c) Terrace/Open Space Access}

The data collected based on the questions in this parameter show that $62.5 \%$ or 5 out of 8 respondents have access to the open spaces near their room, especially for sunbathing activities during the isolation period, as reflected in $75 \%$ of respondents stating the feasibility of the area (Figure 6). However, the patient's method of accessing the open space is not completely sterile because some of them still need to cross other co-sharing rooms that are still accessible to healthy members. Some examples of open spaces used for sunbathing respondents can be seen in Figure 7. Unsatisfactory results also appeared in the parameters of the 'availability of educational information boards', where all respondents stated that they did not have these facilities. This is very unfortunate because an information board is one of the criteria for an isolation room from the Ministry of Health. This standard is intended to provide the latest updated information related to the disease and its treatment and information about emergency contacts. 


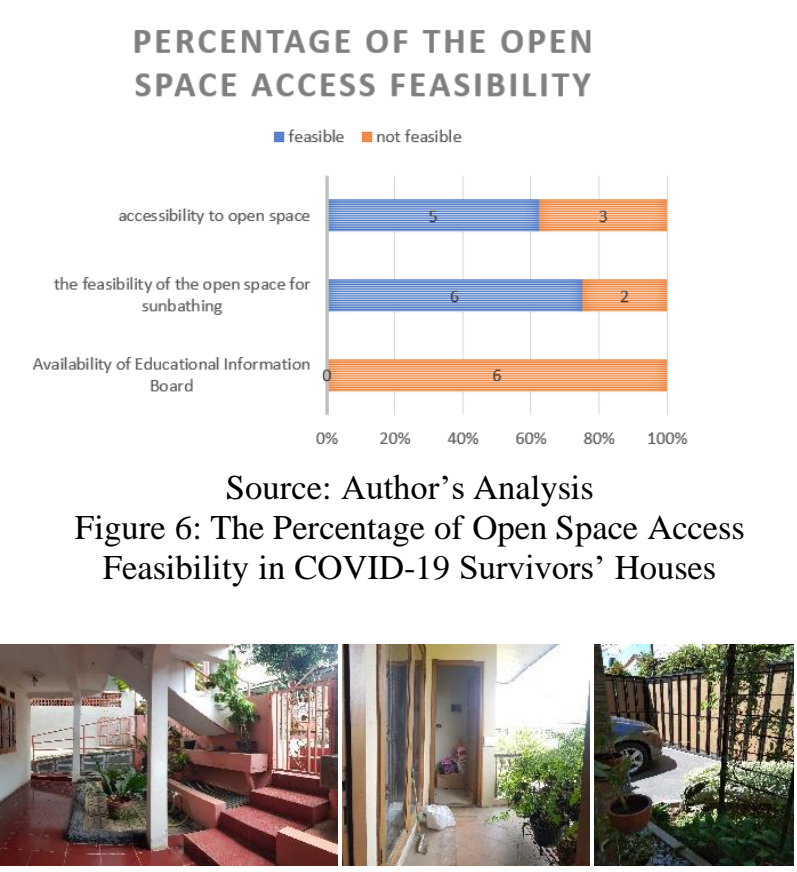

Source: Respondent's Documentation Figure 7: The Open Space Area in COVID-19

Survivors' Houses for Sunbathing

\section{d) Location}

The house's location also became another parameter of the assessment. This parameter reviewed the feasibility of the house accessibility, environmental conditions, and potential for disaster threats. From the results obtained in Figure 8, it can be seen that there is a house that has a high risk of disasters. It's a house located in the Central Jakarta area where it's included in the flood-prone area. Two houses have limited access to four-wheeled vehicles. It might be because these houses are located in densely populated areas, as they filled the option of 'the distance between houses is $<2 \mathrm{~m}$ (COVID-19, 2020).

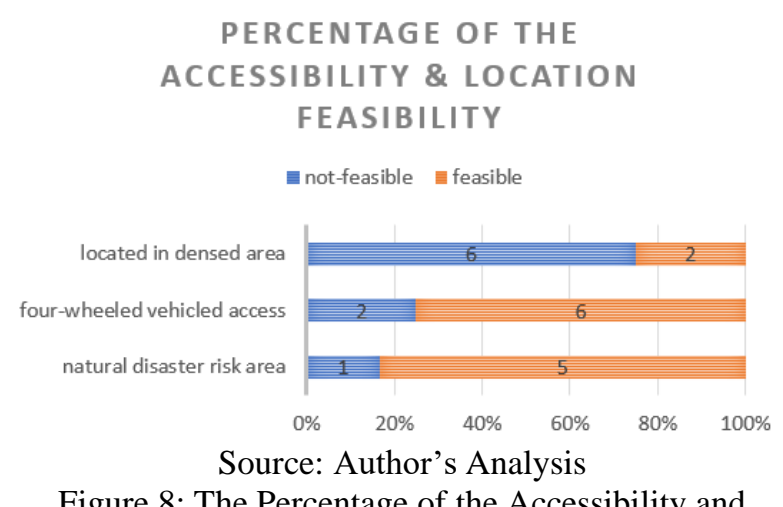

Figure 8: The Percentage of the Accessibility and Location Feasibility in COVID-19 Survivors' Houses

In the same parameter (Figure 9), 62\% of residences' house front road sized $<3$ meters which can be seen, for example, in Figure 10. It's an important note as an effort to mitigate house fires or for medical evacuation. The road in front of the house or the main road near it should be crossed by a fire engine and as ambulance access if needed at any time.

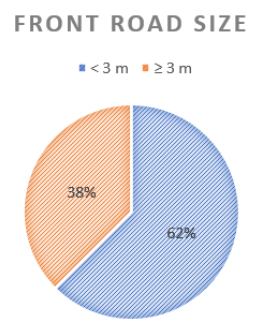

Source: Author's Analysis

Figure 9: The Percentage of the Front Road Size at COVID-19 Survivors' Houses
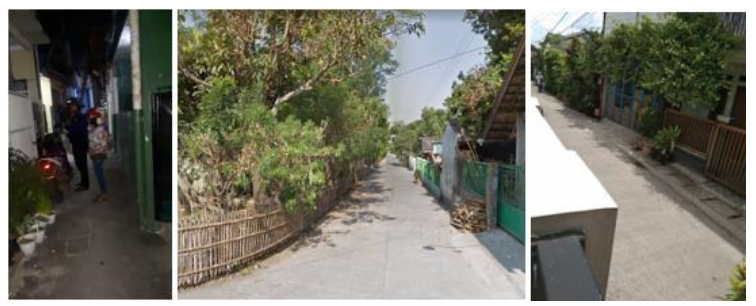

Source: Respondent's Documentation Figure 10: The Front Road Situation at COVID-19 Survivors' Houses 
e) Availability of Clean Water

The recommendation to always maintain the hygienist, by washing hands with soap ( $\mathrm{Cuci}$ Tangan Pakai Sabun-CTPS), taking a bath after coming back home, and so on, is the main reason for a house to have a source of clean water that is proper and always hygienic (figure 11). Even though $87.5 \%$, or 7 out of 8 respondents, already have a CTPS and a suitable place to wash clothes/cutlery, not all of them carried out the disinfection routine of their clean water sources. Only two families practiced this excellent habit. They should be more aware of maintaining the clean water sources quality, one of which is by providing education on proper disinfection for clean water sources. The majority of clean water sources are from PDAM. Therefore the disinfection process can be carried out in temporary storage containers at the houses after the water from PDAM flows. The standard distance between a clean water source (Sumur/Sumber Air Bersih/SAB) and a dirty water infiltration well (Sumur Peresapan Air Kotor/SPAK) or septic tank based is 8 meters. After being reviewed, from the eight respondents, $50 \%$ of dwellings were not following the placement of the septic tank/SPAK from the SAB (Figure 12). This might affect the quality of clean water in the future. In Figure 13, you can see an example of the location of SPAK and SAB in the respondent's residence.

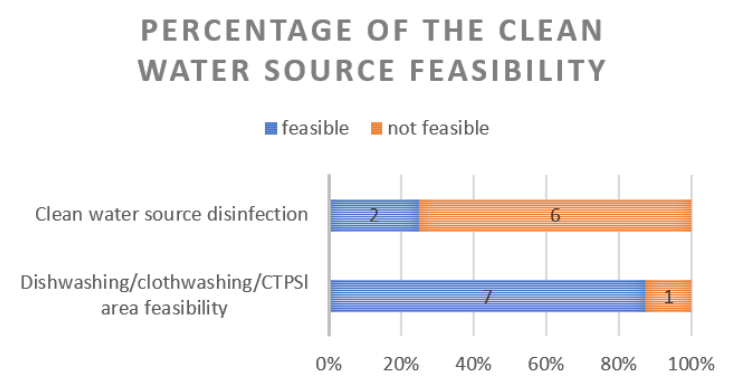

Source: Author's Analysis

Figure 11: The Percentage of the Clean Water Source Feasibility in COVID-19 Survivors' Houses
THE DISTANCE OF SAB AND SPAK

$-<8 \mathrm{~m}=28 \mathrm{~m}$

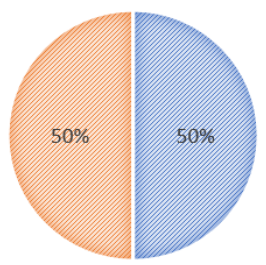

Source: Author's Analysis

Figure 12: The Distance of SAB and SPAK in COVID19 Survivors' Houses

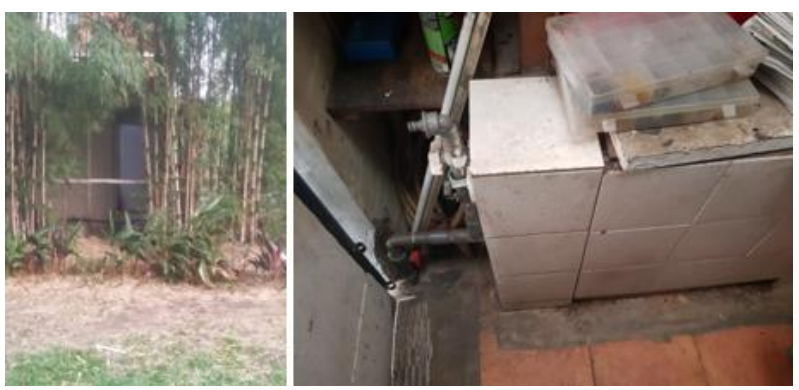

Source: Respondent's Documentation

Figure 13: Sample Location of SPAK (left) and SAB (right) at COVID-19 Survivors' Houses

\section{f) Handwashing Facilities with Soap (CTPS)}

The standards set by the Ministry of Health regarding Hand Washing Facilities With Soap (Cuci Tangan Pakai Sabun-CTPS) are: 1) the availability of CTPS in the separated isolation room, 2) availability of tissue/drying cloth, 3) availability of trash bins in the isolation room, 4) availability of waste-sorting procedures and 5) availability of hand sanitizer. Based on the graph in Figure 14, among eight respondents, there are $50 \%$ who didn't have CTPS facilities separately from other residents (it was located outside the isolation room and co-shared with other family members), yet 7 of 8 respondents confirmed the availability of tissue/drying cloth near the CTPS. This condition is a future note that education about the co-sharing CTPS should be avoided to minimize the virus transmission in a house. All of the respondents stated that there was always a hand sanitizer in their isolation room. Furthermore, $87.5 \%$ of 
respondents confirmed the availability of trash bins in isolation rooms, however in the same percentage, they didn't have proper wastesorting procedures, especially in isolation rooms. This condition is an essential concern because education regarding the sorting of infectious and non-infectious waste must be conveyed clearly by health workers who monitor the patients and other family members to minimize the virus transmission.

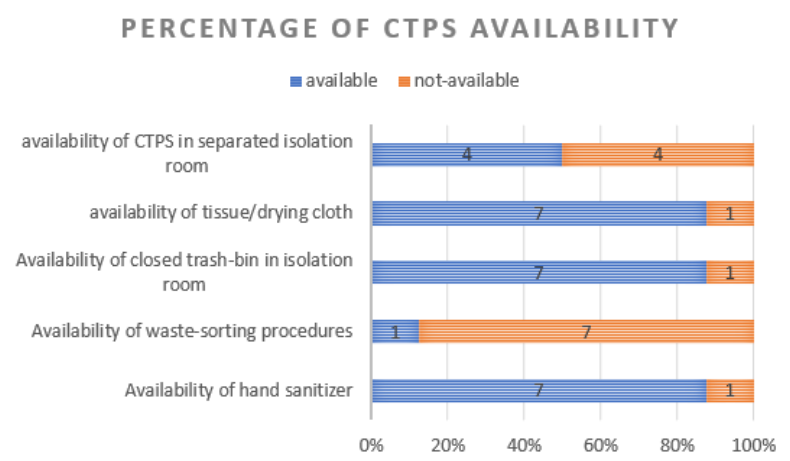

Source: Author's Analysis

Figure 14: The Percentage of CTPS Availability in COVID-19 Survivors' Houses

The majority of CTPS facilities were in the form of a sink. Meanwhile, respondents who answered that CTPS was outside the isoman room were faucets with a bucket in the bathroom/washing room, and the rest responded that they washed their hands directly on the bathroom faucet. The sinks' sizes also vary, some ranging from $50 \times 75 \mathrm{~cm}$ and $40 \times 60$ $\mathrm{cm}$ (figure 15).

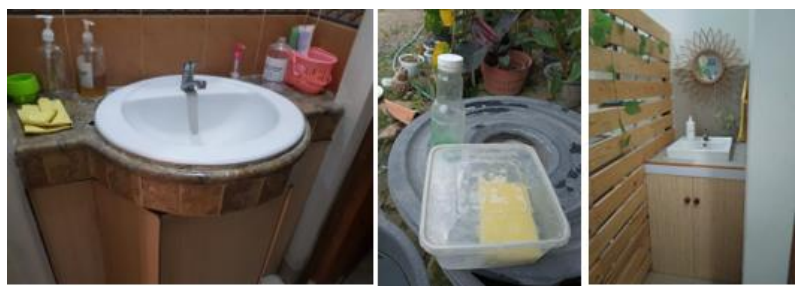

Source: Respondent's Documentation

Figure 15: Sample of CTPS facilities in COVID-19 Survivors' Houses

\section{g) Bathrooms}

Bathrooms should have become one of the primary standards in every healthy house. During the COVID-19 pandemic, some rules must be observed. All of the bathrooms in the respondent's residence were considered feasible since it provided the bathroom amenities and were routinely disinfected. It was stated in the percentage of $75 \%$ (Figure 16). However, it also can be seen that there are still more than half of the respondents $(62.5 \%)$ who didn't have a separate bathroom from the other family members. This is quite worrying because cosharing access allows the high-risk virus transmission rate. The quality of the bathroom feasibility is also different, as can be seen in Figure 17. As stated in the RI Ministry of Health protocol (COVID-19, 2020), the bathroom amounts in a house should be evaluated by considering the number of family members ( to minimize the queues), separating the bathrooms for vulnerable groups (e.g., the elderly, disabled, etc.). In addition, we have to make sure that there is adequate lighting in the bathroom and on the connection to the bedrooms. Even gender privacy should be considered.

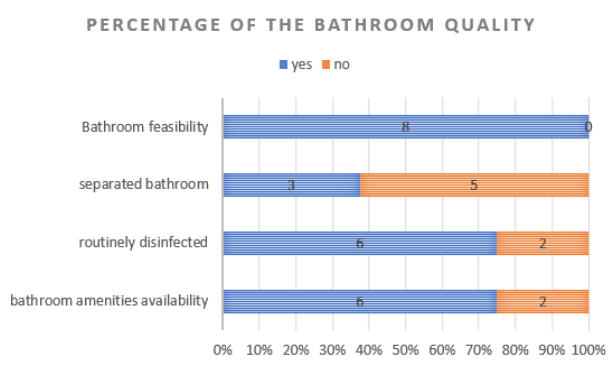

Source: Author's Analysis

Figure 16: The Percentage of Bathroom Quality in COVID-19 Survivors' Houses

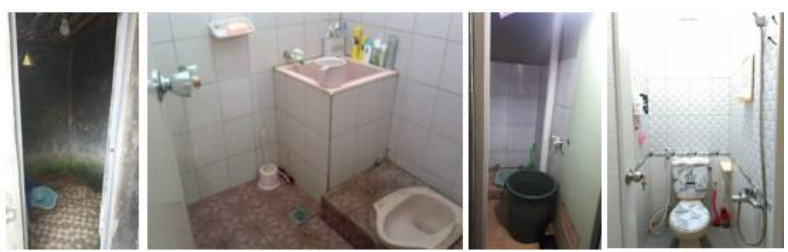

Source: Respondent's Documentation

Figure 17: Bathrooms in Several COVID-19 Survivors' Houses 


\section{h) Laundry Facility}

The laundry room for the infected person must be separated and must be soaked in detergent upon putting it in the washing machine. The patients or anyone who helped the patient must wear masks and rubber gloves to do the laundry. They also need to wash their hands with soap for 20 seconds after washing the clothes. In the results of the questionnaire that eight survivors have filled out, it can be seen that $75 \%$ of the families of the survivors have not separated the laundry facilities, do not have a particular drying room near the isolation room (it's still a co-sharing laundry room), and still in lack of awareness about the importance of masks and rubber gloves when doing the laundry to prevent transmission through water (Figure 18 and 19).

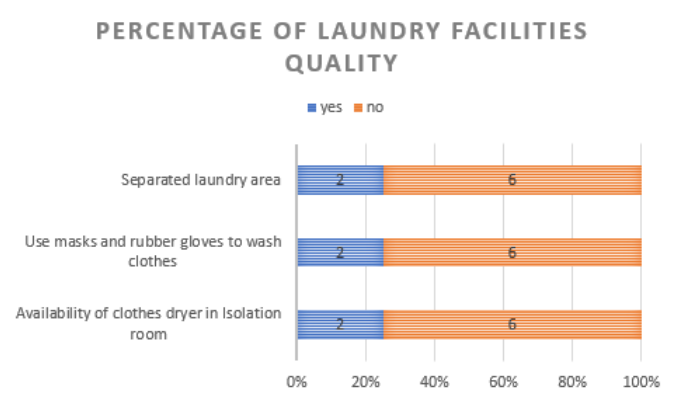

Source: Author's Analysis

Figure 18: The Percentage of Laundry Facilities Quality in COVID-19 Survivors' Houses
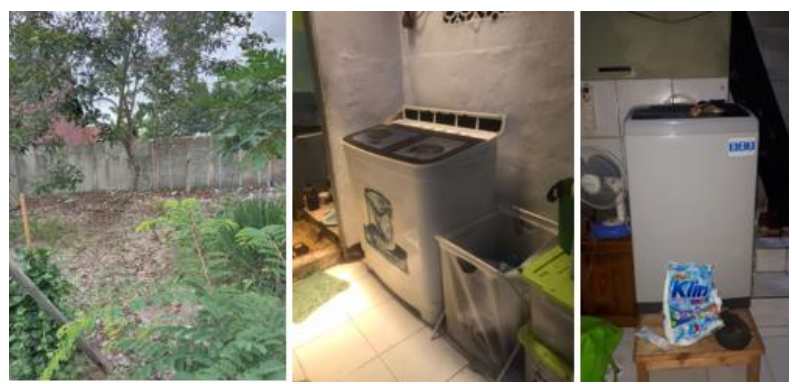

Source: Respondent's Documentation

Figure 19: Laundry Facilities in COVID-19 Survivors' Houses i) Sanitation And Drainage System

Based on the Ministry of Health's protocol (COVID-19, 2020), proper sanitation and drainage standards for healthy housing are:

1. The availability of water channels that directly flow to the outside environment.

2. Water channels are directly connected to the Waste Water Treatment Plant/WWTP (Instalasi Pengolahan Air Limbah-IPAL) or to the septic tank.

3. The condition of the septic tank must comply with SNI standards.

From the diagram in Figure 20, it can be seen that $50 \%$ of respondents have proper WWTP, and 7 out of 8 houses have sewers near them. Meanwhile, $62.5 \%$ of respondents have a septic tank that meets SNI standards and has greywater drainage from the bathroom/toilet/sink/wash tables, directly channeled to the septic tank/WWTP. The public should be better educated about the importance of separating greywater from the isolation room to prevent any virus/bacteria transmission through the waste/greywater.

PERCENTAGE OF SANITATION AND DRAINAGE FEASIBILITY

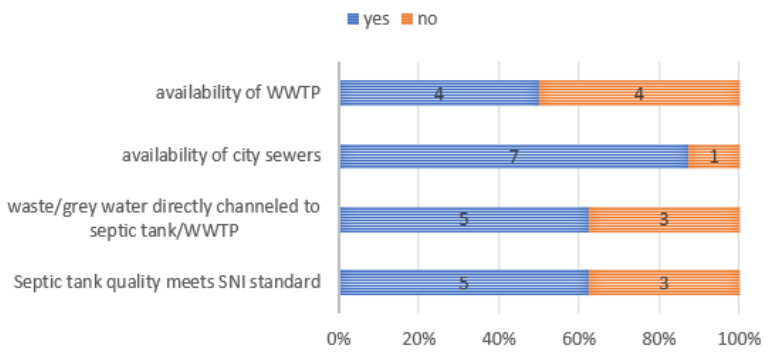

Source: Author's Analysis

Figure 20: The Percentage of Sanitation and Drainage Feasibility in COVID-19 Survivors' Houses

\section{j) Trash / sewage management}

As shown in Figure 21, only two respondents stated that they had infectious and noninfectious waste sorting procedures in their isolation room. Some of their trash bins were inside and outside the isolation room (figure 22). Moreover, $67.5 \%$ of all respondents stated that the trash from their isolation room is still 
mixed with household waste, and $100 \%$ is not separated by category in environmental waste (outside the house). According to the Ministry of Health protocol standards, waste from the isolation room should be put in a separate plastic placed in the room. The responsible party must use a mask and gloves when it is collected. Then after taking and disposing of the garbage, the person must wash his hands with soap. In addition, there must be education on handling infectious waste and communication with the health office regarding waste management, including infectious waste, tissue waste, contaminated fluid waste, and sanitary napkins.

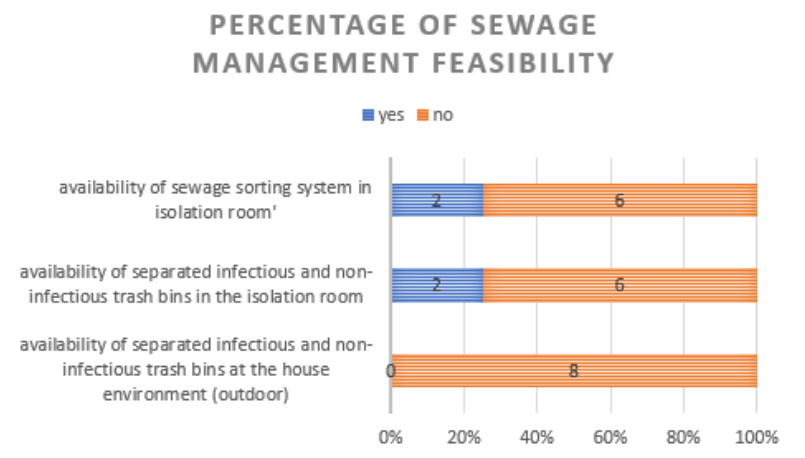

Source: Author's Analysis

Figure 21: The Percentage of Sewage Management in COVID-19 Survivors' Houses
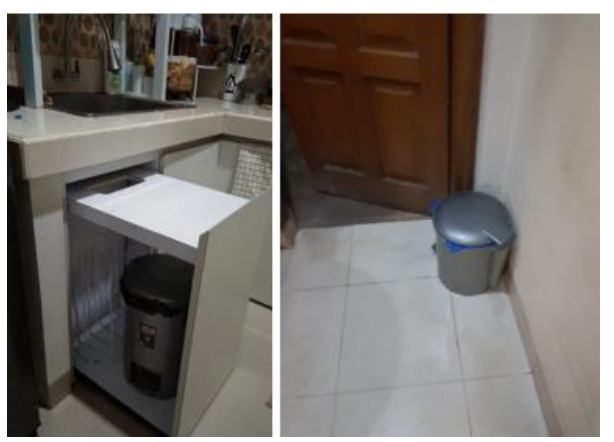

Source: Respondent's Documentation Figure 22: Trash Bins in COVID-19 Survivors' Houses

\section{k) Food Logistics}

This parameter is significant because it is closely related to the primary needs of COVID19 patients. The isolated person must comply with several strict health protocols related to accessibility, especially for getting food supplies at least three times a day. Having the same percentage, $62 \%$, the respondents stated that they received food supplies from their families, had separated drinking water facilities, and received food outside the isoman room (Figure 23). The rest of them answered that they got their food supply from delivery service, and it was usually placed in front of their house. However, some respondents answered that the logistics of taking food were given inside an isoman room inside the outside. This phenomenon needs to be fixed because it indicates that there is still potential for direct contact between patients and healthy parties. All family members should be given additional education about the importance of maintaining contact restrictions, even with their own families.

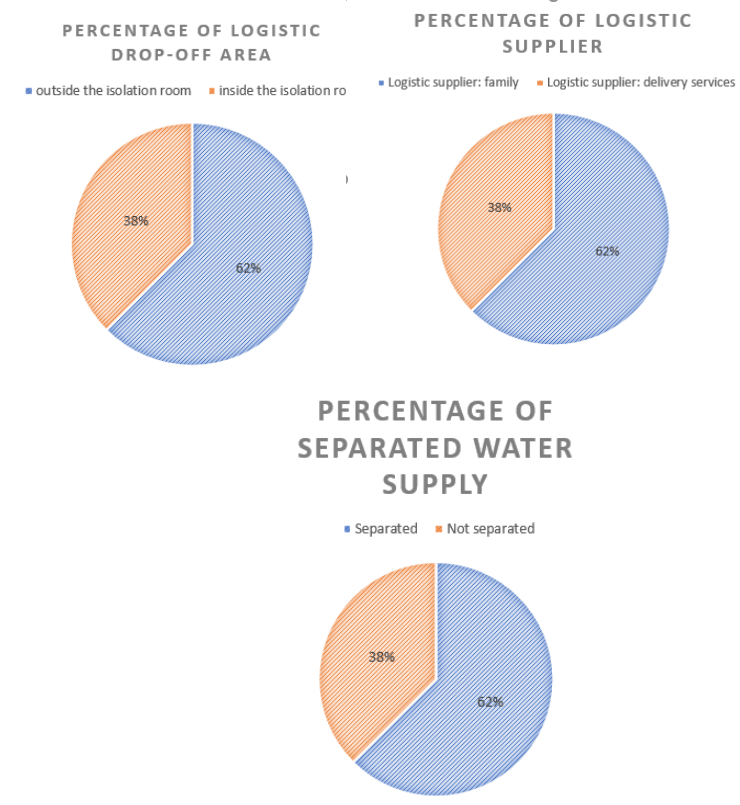

Source: Author's Analysis

Figure 23: The Percentage of Food logistics parameter in COVID-19 Survivors' Houses 


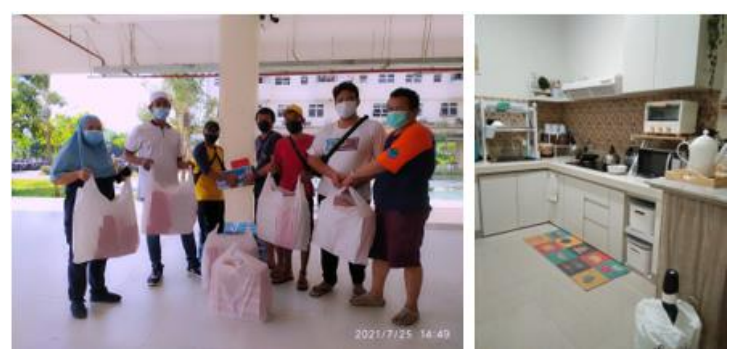

Source: Respondent's Documentation

Figure 24: Food Logistics Provider, From family/neighbourhood (left) and kitchen to cook food themselves (right)

\section{Conclusion}

From the results and discussion, it can be concluded that:

- The potential for the COVID-19 virus transmission in a house is high because some isolation room parameters still do not suit the standards. This can be caused by several mixed activities, such as the bathroom that are still integrated due to social and economic factors, the lack of awareness for disinfecting the water sources, unseparated laundry area, the inadequate and unsorted garbage disposal, and the misconception of food supply dropping area.

- The feasibility of waste management becomes the most significant red report card from the above discussion results. All respondents did not have a proper separated procedure for the waste management system and still had mixed sanitation.

- In addition, most respondents have an excellent clothes-drying area in their isolation room because they still rely on the same laundry activities with other family members.

- The majority of COVID-19 patients use an existed bedroom in their residence to become their isolation room. One thing that must be highlighted is the obligation to separate the room from other residents.

- All of these conditions can be prevented by providing recommendations for room rearrangement in the house by considering the procedures that become the standard reference for the feasibility of an independent isolation room.

\section{Acknowledgement}

This research is a grant from Ministry of Higher Education entitled "Program Kompetisi Kampus Merdeka” (PKKM) 2021.

\section{References}

[1] Satwikasari, A. F. 2015. Penilaian Kualitas Lingkungan Fisik Permukiman yang Berpengaruh terhadap Prevalensi Tuberkulosis (TB). Studi Kasus: Kabupaten Kebumen, Jawa Tengah. Thesis Arsitektur Institut Teknologi Bandung

[2] Satwikasari, A. F. 2018. Exploratory Study of Physical Environment Factors Affecting Tuberculosis Endemics Houses in Kebumen District, Indonesia. International Journal of Built Environment and Scientific Research, 65-74.

[3] Satwikasari, A.F., Hakim, L., Prayogi, L., 2018. Enhancing Thermal Environment Quality with Voids and Indoor Gardens as a Passive Design Strategy towards Sustainable and Healthy Living . International Journal of Technology. Volume 9(7), pp. 1384-1393

[4] Organization, W. H. (2020). Coronavirus. Retrieved from World Health Organization: https://www.who.int/health-topics/coronavirus Organization, W. H. (2020). Global Tuberculosis Report . Geneva: World Health Organization.

[5] JD, R. S. (2007). Guideline for Isolation Precautions: Preventing Transmission of Infectious Agents in Healthcare Settings. Retrieved from Centers for Disease Control and Prevention https:/www.cdc.gov/infectioncontrol/guidelines/isolatio n/index.html

[6] COVID-19, G. T. (2020). Protokol Penyiapan Fasilitas Shelter Untuk Karantina Dan Isolakolektif Di

Fasilitas Umum Berbasis Masyarakat Di Masa Pandemi Covid-19. Jakarta.

[7] RI, K. K. (2020). Pedoman Pencegahan dan Pengendalian Coronavirus Disease (COVID-19). Jakarta: Kementerian Kesehatan RI.

[8] Indonesia, K. K. (2020). Protokol Isolasi Diri Sendiri Dalam Penanganan COVID-19. Jakarta: Kementerian Kesehatan Republik Indonesia.

[9] Yusuf Ariyanto, W. W. (2021). Modul Unit Karantina Portable Sebagai Fasilitas Pembantu Ruang Isolasi. SHARE (Journal of Service Learning), , 78-85.

[10] Kusuma, H. E. (2012). Memilih Metode Analisis Kuantitatif Untuk Penelitian Arsitektur. Bandung. 